\title{
The Effectiveness of the Carburizing Process on ST 42 Steel With Variations of Donor Media
}

\section{Efektifitas Proses Karburasi Pada Baja ST 42 Dengan Variasi Media Donor}

\author{
Hesti Istiqlaliyah $^{1}$, Mohammad Muslimin Ilham ${ }^{2}$ \\ [hestiisti@unpkediri.ac.id]
}

Teknik Mesin, Universitas Nusantara PGRI Kediri ${ }^{1,2}$

\begin{abstract}
Carburizing is a process of adding carbon content in steel by using solid media. This study aims to determine the effectiveness of the carburizing process on the hardness and depth of carbon diffusion on ST 42 steel with a variety of donor media. Meanwhile, the donor media used were teak wood charcoal, coconut shell charcoal, and graphite. The results of this study are the highest level of hardness in coconut shell charcoal, namely $815.39 \mathrm{HV}$, teak charcoal $715.5 \mathrm{HV}$, and the lowest hardness is graphite at $343.975 \mathrm{HV}$. While the highest average carburizing depth was coconut shell charcoal of $0.0133 \mu$, teak charcoal at $0.0085 \mu$, and graphite by $0.00416 \mu$. This shows that there are differences in the hardness value and the depth of carbon diffusion in the three types of donor media used in the carburizing process, so it can be concluded that the type of donor media can also affect the effectiveness of the carburizing process itself.
\end{abstract}

Keywords - Carburizing; Effectiveness; Media Donors.

\begin{abstract}
Abstrak. Karburasi adalah salah satu proses penambahan kandungan karbon didalam baja dengan menggunakan media padat. Penelitian ini bertujuan untuk mengetahui efektifitas proses karburasi terhadap kekerasan dan kedalaman difusi karbon pada Baja ST 42 dengan variasi media donor. Sedangkan media donor yang digunakan adalah arang kayu jati, arang tempurung kelapa, dan grafit. Hasil dari penelitian ini adalah tingkat kekerasan tertinggi pada arang tempurung kelapa yaitu 815,39 HV, arang kayu jati 715,5 HV, dan kekerasan terendah ada pada grafit sebesar 343,975 HV. Sedangkan rata-rata kedalaman karburasi terbesar adalah arang tempurung kelapa sebesar $0,0133 \mu$, arang kayu jati sebesar 0,0085 $\mu$, dan grafit sebesar 0,00416 $\mu$. Hal ini menunjukkan bahwa terdapat perbedaan nilai kekerasan dan kedalaman difusi karbon pada ke tiga jenis media donor yang digunakan pada proses karburasi, sehingga dapat ditarik kesimpulan bahwa jenis media donor juga dapat mempengaruhi efektifitas proses karburasi itu sendiri.
\end{abstract}

Kata Kunci-Efektifitas; Karburasi; Media Donor.

\section{Pendahuluan}

Dimasa sekarang penggunaan logam sangatlah luas, tidak hanya terbatas pada logam sebagai rangka atau bahan pembuatan perkakas permesinan saja. Melainkan segala aspek kehidupan sudah mulai dikembangkan berbahan baku logam. Dengan demikian kebutuhan logam dengan kualitas yang baguspun menjadi primadona. Akan tetapi seperti yang kita ketahui bahwa logam dengan kualitas yang bagus memiliki harga di atas rata-rata. Sehingga produsen harus berfikir ulang ketika memutuskan untuk memilih jenis logam yang digunakan, terutama material baja. Baja sendiri dikelompokkan menjadi tiga jenis berdasarkan kadar kandungan karbonnya, yaitu baja karbon tinggi, baja karbon sedang dan baja karbon rendah [1]. Pada penelitian ini menggunakan baja dengan nomor ST42 yang termasuk kedalam golongan baja dengan kadar karbon rendah, dengan kandungan karbon kurang dari 0,25\%.

Proses peningkatan kekerasan logam itu sendiri sebetulnya dapat dilakukan dengan berbagai cara, salah satunya yaitu dengan proses karburasi. Karburasi adalah proses perlakuan panas dengan cara menambahkan karbon pada permukaan logam guna mendapatkan struktur mikro dan sifat yang diinginkan [2]. Karburasi ini adalah cara pengerasan permukaan yang sangat umum digunakan. Pada umumnya proses carburizing diikuti dengan pendinginan cepat (quenching) untuk meningkatkan kekerasannya sehingga atom karbonnya lebih banyak dalam permukaannya. Unsur karbon dalam proses carburizing bisa berasal dari karbon arang kayu, arang tempurung kelapa, grafit, batubara, dll.

Pada proses karburasi, ketika suhu mengalami kenaikan akan terjadi pendifusian karbon kedalam permukaan logam. Atom-atom akan bergetar dengan energi yang lebih besar, dan sejumlah kecil atom akan berpindah dalam kisi. Bila atom mengisi kekosongan, maka terjadi lubang atau kekosongan baru. Kekosongan baru ini dapat diisi oleh atom lain yang berasal dari tetangga mana saja. Sebagai hasil akhir dapat dikatakan bahwa atom melakukan gerak acak dalam kristal. Mekanisme gerak acak dapat diterapkan pada atom karbon yang bergerak diantara atom besi, dari posisi sisipan yang satu keposisi sisipan berikutnya. Proses difusi yang terjadi pada baja karbon rendah (yang tangguh tetapi 
lunak) dipanaskan dalam lingkungan yang mengandung karbon, sehingga karbon berdifusi dalam baja, menghasilkan selubung luar yang kaya akan karbon dan keras [3].

Proses karburasi dapat dipengaruhi oleh beberapa faktor, diantaranya adalah temperatur pemanasan. Temperatur yang digunakan pada proses karburasi akan mempengaruhi jumlah atom yang berdifusi melewati luasan media acceptor. Bila suhu naik, atom-atom akan bergetar dengan energi yang lebih besar, dan sejumlah atom akan berpindah dalam kisi [3]. Pada penelitian ini akan menggunakan temperatur $950^{\circ} \mathrm{C}$, hal ini di karenakan kandungan karbon baja St 42 yaitu $0,7-0,1 \%$ yang apabila di tarik menurut grafik smallman maka akan didapatkan suhu $950^{\circ} \mathrm{C}$ untuk mendapatkan suhu austenit. Yang ke dua adalah waktu penahanan, hal ini berpengaruh pada banyaknya karbon yang berdifusi ke dalam material, karena semakin lama waktu penahanan maka semakin besar pula energi aktivasi yang diperoleh karbon untuk melakukan difusi [4]. Pada penelitian ini menggunakan waktu penahanan selama 1 jam. dan selanjutnya adalah media donor [5]. Bahan karburasi aktif, biasanya adalah arang atau campuran antara arang kayu, arang bambu dan arang tempurung kelapa, arang kulit dan tulang hewan. Bongkahan arang tersebut dihaluskan hingga menjadi serbuk yang homogen. Dalam penelitian ini menggunakan tiga jenis arang, yaitu arang tempurung kelapa, arang kayu jati dan grafit.

\section{METODE}

Metode yang digunakan dalam penelitian ini adalah eksperimental yang bertujuan untuk mengungkapkan hubungan sebab akibat antara variabel. Variabel yang dipilih dalam penelitian ini sendiri yaitu, variabel terikatnya adalah nilai kekerasan dan kedalaman difusi karbon pada permukaan baja. Sedangkan variabel bebasnya adalah jenis media donor yang digunakan pada proses karburasi, yaitu arang tempurung kelapa, arang kayu jati dan grafit.

Baja yang dipakai dalam penelitian ini adalah baja St 42 berbentuk silinder. Seperti pada gambar 3.2 berikut Spesimen baja ini memiliki ukuran pada setiap spesimen dengan diameter $20 \mathrm{~mm}$ tinggi $20 \mathrm{~mm}$. total semua spesimen yang nantinya akan dikarburasi 24 spesimen dengan bentuk dan ukuran yang sama. Silinder baja karbon tersebut akan dianalisis perbedaan tingkat kekerasan dan kedalaman difusi karbonnya.

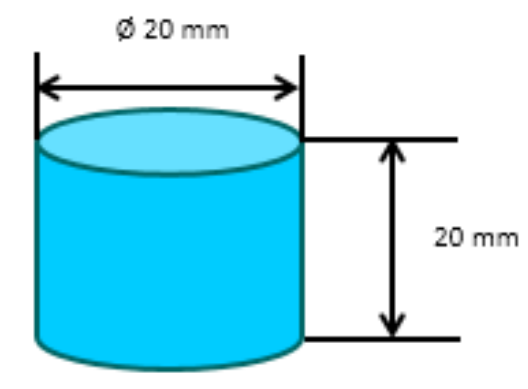

Gambar 1. Bentuk dan Dimensi Spesimen Penelitian

Alur penelitian ini dapat dilihat pada gambar 2, dimana setelah pembentukan spesimen penelitian maka tahapan selanjutnya adalah proses karburasi dengan menggunakan suhu $950^{\circ} \mathrm{C}$ dan waktu penahanan selama kurang lebih 1 jam. Setelah proses karburasi, makadilakukan proses pendinginan secara tiba-tiba atau quenching dengan menggunakan media air. Setelah spesimen siap untuk diuji, maka dilakukan pengujian kekerasan dan kedalaman difusi karbon. Pengujian kekerasan dan kedalaman difusi karbon ini dilakukan waktu sebelum proses karburasi dengan tujuan untuk mengetahui nilai awal kekerasan dan kondisi spesimen uji yang nantinya akan dibandingkan dengan nilai kekerasan dan kedalaman difusi karbon setelah proses karburasi diberikan. Pengujian dimabil sebanyak tiga kali pengulangan, kemudian diambil rata-rata dari ketiga pengulangan tersebut. 


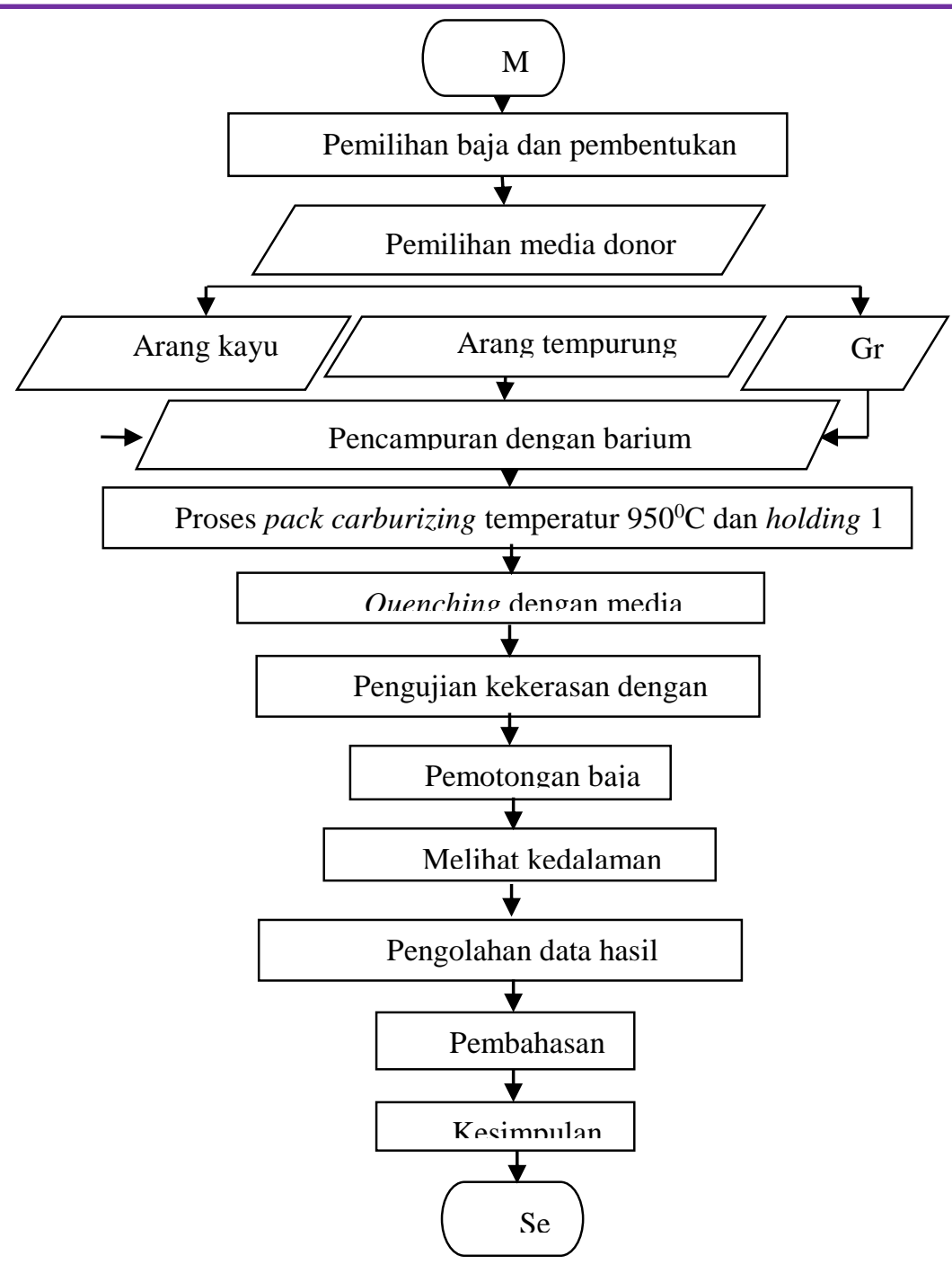

Gambar 2. Alur Penelitian

\section{Hasil dan Pembahasan}

\section{A. Tingkat Kekerasan}

Hasil uji kekerasan untuk spesimen uji tanpa adanya proses karburasi menunjukkan hasil seperti yang terlihat di tabel 1 berikut.

Tabel 1. Hasil Uji Kekerasan Tanpa Perlakuan Panas

\begin{tabular}{cccccc}
\hline \multirow{2}{*}{ No } & \multirow{2}{*}{ Spesimen } & \multicolumn{3}{c}{ Nilai Kekerasan $($ Hv $)$} & \multirow{2}{*}{$\begin{array}{c}\text { Rata - } \\
\text { rata }\end{array}$} \\
\cline { 3 - 6 } & & 1 & 2 & 3 & 193,8 \\
\hline 1 & 1 & 199,4 & 193 & 193,8 & 195,4 \\
\hline
\end{tabular}

Sedangkan hasil pengujian kekerasan spesimen yang telah mengalami proses carburizing dengan menggunakan media donor arang kayu jati pada temperatur $950{ }^{\circ} \mathrm{C}$ dengan penggunaan holding time selama 1 jam yang dilanjutkan quenching dengan media pendingin air. Adapun tabel data tingkat kekerasan tersebut sebagai berikut:

Tabel 2. Hasil Uji Kekerasan Setelah Proses Karburasi Dengan Media Donor Arang Kayu Jati

$\begin{array}{lccc}\text { Media Donor } & \text { Spesime } & \text { Kekerasan Permukaan Pada Uji } & \text { Rata - Rata } \\ & \mathrm{n} & \text { HV } & \text { HV }\end{array}$


Procedia of Engineering and Life Science Conference Vol. 1. No. 1 March 2021

Seminar Nasional \& Call Paper Fakultas Sains dan Teknologi (SENASAINS 1st)

Universitas Muhammadiyah Sidoarjo

\begin{tabular}{|c|c|c|c|c|c|}
\hline & & 1 & 2 & 3 & \\
\hline \multirow[t]{8}{*}{ Arang kayu jati } & $\mathrm{O}_{11}$ & 691,6 & 656,1 & 681,2 & 676,3 \\
\hline & $\mathrm{O}_{12}$ & 691,6 & 824,2 & 691,6 & 735,8 \\
\hline & $\mathrm{O}_{13}$ & 670,9 & 778,1 & 845,2 & 764,73 \\
\hline & $\mathrm{O}_{14}$ & 713,2 & 730,1 & 651,2 & 698,17 \\
\hline & $\mathrm{O}_{15}$ & 753,5 & 592,8 & 641,7 & 662,67 \\
\hline & $\mathrm{O}_{16}$ & 797,4 & 696,9 & 765,7 & 753,33 \\
\hline & $\mathrm{O}_{17}$ & 676 & 730,1 & 753,6 & 719,9 \\
\hline & $\mathrm{O}_{18}$ & 718 & 696,9 & 724,4 & 713,1 \\
\hline
\end{tabular}

Dari tabel 2 dapat dilihat hasil pengujian kekerasan Vickers memiliki angka kekerasan terendah 592,8 HV dan angka kekerasan tertinggi sebesar 845,2 HV. Angka kekerasan rata-rata untuk spesimen $\mathrm{O}_{11}$ adalah 676,3 HV, untuk spesimen $\mathrm{O}_{12}$ menunjukkan nilai $735,8 \mathrm{HV}$, untuk spesimen $\mathrm{O}_{13}$ adalah 764,73 HV, untuk spesimen $\mathrm{O}_{14}$ adalah 698,17 $\mathrm{HV}$, untuk spesimen $\mathrm{O}_{15}$ adalah 662,67 $\mathrm{HV}$, untuk spesimen $\mathrm{O}_{16}$ adalah 753,33 HV, untuk spesimen $\mathrm{O}_{17}$ adalah 719,9 $\mathrm{HV}$, dan untuk spesimen $\mathrm{O}_{18}$ adalah $713,1 \mathrm{HV}$. Sehingga angka rata-rata untuk tingkat kekerasan kedelapan spesimen pada baja St 42 setelah mengalami proses carburizing dengan menggunakan arang kayu jati pada temperatur $950{ }^{\circ} \mathrm{C}$ yang kemudian didinginkan dengan media pendingin air dalam skala Vickers menunjukkan angka rata-rata 715,5 $\mathrm{HV}$.

Tabel 3. Hasil Uji Kekerasan Setelah Proses Karburasi Dengan Media Donor Arang Tempurung Kelapa

\begin{tabular}{|c|c|c|c|c|c|}
\hline \multirow{2}{*}{ Media Donor } & \multirow{2}{*}{$\begin{array}{l}\text { Spesim } \\
\text { en }\end{array}$} & \multicolumn{3}{|c|}{ Kekerasan Permukaan Pada Uji HV } & \multirow{2}{*}{$\begin{array}{l}\text { Rata - Rata } \\
\mathrm{HV}\end{array}$} \\
\hline & & 1 & 2 & 3 & \\
\hline \multirow{8}{*}{$\begin{array}{l}\text { Arang } \\
\text { kelapa }\end{array}$} & $\mathrm{O}_{21}$ & 724,4 & 845,2 & 741,7 & 770,43 \\
\hline & $\mathrm{O}_{22}$ & 845,2 & 824,2 & 815,2 & 828,2 \\
\hline & $\mathrm{O}_{23}$ & 889,6 & 905 & 937 & 910,53 \\
\hline & $\mathrm{O}_{24}$ & 874,5 & 852,4 & 838,1 & 855 \\
\hline & $\mathrm{O}_{25}$ & 718,8 & 735,9 & 696,9 & 717,2 \\
\hline & $\mathrm{O}_{26}$ & 810,6 & 824,2 & 804 & 812,93 \\
\hline & $\mathrm{O}_{27}$ & 838,1 & 824,2 & 824,2 & 828,83 \\
\hline & $\mathrm{O}_{28}$ & 790,9 & 831,1 & 778,1 & 800,03 \\
\hline Rata - rata & & & & & 815,39 \\
\hline
\end{tabular}

Dari tabel 3 dapat dilihat hasil pengujian kekerasan Vickers memiliki angka kekerasan terendah 696,9 HV dan angka kekerasan tertinggi sebesar $937 \mathrm{HV}$. Angka kekerasan rata-rata untuk spesimen $\mathrm{O}_{21}$ adalah 770,43 $\mathrm{HV}$, untuk spesimen $\mathrm{O}_{22}$ menunjukkan nilai 828,2 $\mathrm{HV}$, untuk spesimen $\mathrm{O}_{23}$ adalah 910,53 HV, untuk spesimen $\mathrm{O}_{24}$ adalah 855 $\mathrm{HV}$, untuk spesimen $\mathrm{O}_{25}$ adalah 717,2 $\mathrm{HV}$, untuk spesimen $\mathrm{O}_{26}$ adalah $812,93 \mathrm{HV}$, untuk spesimen $\mathrm{O}_{27}$ adalah 828,83 $\mathrm{HV}$, dan untuk spesimen $\mathrm{O}_{28}$ adalah $800,03 \mathrm{HV}$. Sehingga angka rata-rata untuk tingkat kekerasan kedelapan spesimen pada baja St 42 setelah mengalami proses carburizing dengan menggunakan arang tempururng kelapa pada temperatur $950{ }^{\circ} \mathrm{C}$ yang kemudian didinginkan dengan media pendingin air dalam skala Vickers menunjukkan angka rata-rata $815,39 \mathrm{HV}$.

Tabel 4. Hasil Uji Kekerasan Setelah Proses Karburasi Dengan Media Donor Grafit

\begin{tabular}{|c|c|c|c|c|c|}
\hline \multirow{3}{*}{$\begin{array}{l}\text { Media } \\
\text { Donor }\end{array}$} & \multirow{3}{*}{ en } & Kekerasan & Permukaan & Pada Uji & \multirow{3}{*}{$\begin{array}{l}\text { Rata - Rata } \\
\text { HV }\end{array}$} \\
\hline & & \multicolumn{3}{|l|}{ HV } & \\
\hline & & 1 & 2 & 3 & \\
\hline \multirow[t]{8}{*}{ Grafit } & $\mathrm{O}_{31}$ & 247,5 & 252,1 & 255,6 & 251,73 \\
\hline & $\mathrm{O}_{32}$ & 302,8 & 328,8 & 356,4 & 329,33 \\
\hline & $\mathrm{O}_{33}$ & 368,4 & 374,6 & 385,4 & 376,13 \\
\hline & $\mathrm{O}_{34}$ & 392 & 403,5 & 413,1 & 402,93 \\
\hline & $\mathrm{O}_{35}$ & 408,3 & 360,4 & 304,3 & 357,67 \\
\hline & $\mathrm{O}_{36}$ & 350,2 & 402,7 & 390,6 & 381,17 \\
\hline & $\mathrm{O}_{37}$ & 413 & 387,6 & 408,3 & 402,97 \\
\hline & $\mathrm{O}_{38}$ & 241,9 & 252,1 & 255,6 & 249,87 \\
\hline Rata - rat & rasan & & & & 343,975 \\
\hline
\end{tabular}


Dari tabel 4.4 dapat dilihat hasil pengujian kekerasan Vickers memiliki angka kekerasan terendah 241,9 HV dan angka kekerasan tertinggi sebesar $413 \mathrm{HV}$. Angka kekerasan rata-rata untuk spesimen $\mathrm{O}_{31}$ adalah $251,73 \mathrm{HV}$, untuk spesimen $\mathrm{O}_{32}$ menunjukkan nilai $329,33 \mathrm{HV}$, untuk spesimen $\mathrm{O}_{33}$ adalah $376,13 \mathrm{HV}$, untuk spesimen $\mathrm{O}_{34}$ adalah 402,93 HV, untuk spesimen $\mathrm{O}_{35}$ adalah $357,67 \mathrm{HV}$, untuk spesimen $\mathrm{O}_{36}$ adalah $381,17 \mathrm{HV}$, untuk spesimen $\mathrm{O}_{37}$ adalah 402,97 HV, dan untuk spesimen $\mathrm{O}_{38}$ adalah 249,87 HV. Sehingga angka rata-rata untuk tingkat kekerasan kedelapan spesimen pada baja St 42 setelah mengalami proses carburizing dengan menggunakan media donor grafit pada temperatur $950{ }^{\circ} \mathrm{C}$ yang kemudian didinginkan dengan media pendingin air dalam skala Vickers menunjukkan angka rata-rata 343,975 HV. Dari beberapa tabel hasil pengujian kekerasan vickers diatas, maka tabel nilai kekerasan untuk baja St 42 dapat disederhanakan menjadi tabel 4.5 dibawah ini sehingga dapat terlihat kenaikan maupun penurunan nilai kekerasan pada baja St 42 yang telah mengalami proses carburizing dengan variasi media donor arang kayu jati, arang tempurung kelapa, dan grafit.

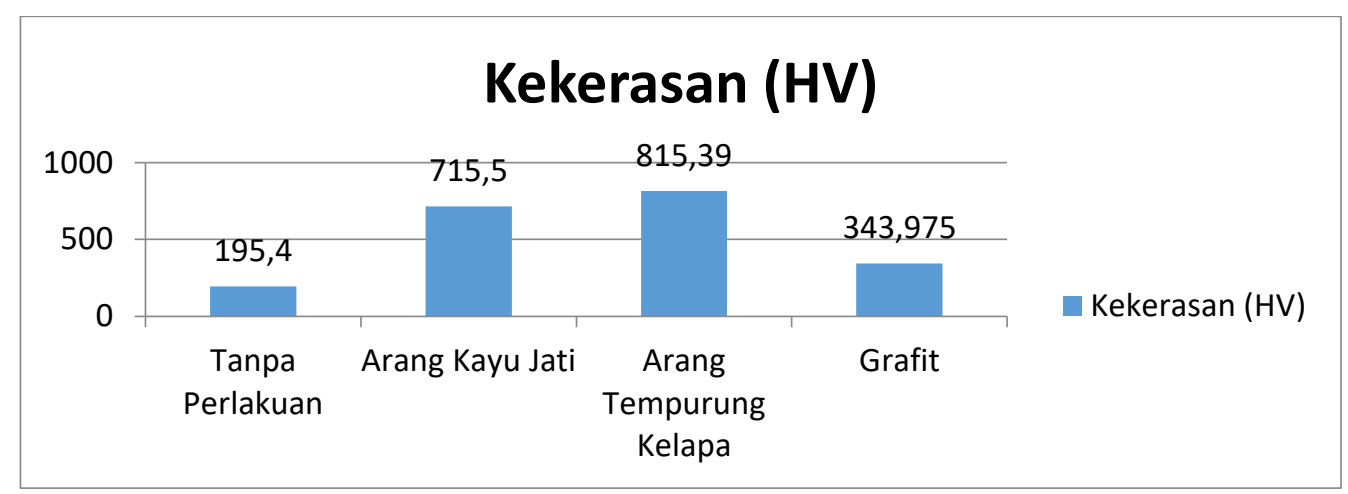

Gambar 3. Hasil Uji Kekerasan Menggunakan Variasi Media Donor

\section{B. Kedalaman Difusi Karbon}

Setelah dilakukan pengujian kekerasan Vickers terhadap spesimen yang telah mengalami carburizing dengan variasi media donor yang dilanjutkan dengan quenching dengan media pendingin air, maka langkah berikutnya adalah pengambilan foto mikro dengan tujuan melihat kedalaman karburasi karbon yang ada pada permukaan spesimen. Adapun foto mikro yang dilakukan ini setiap variasi di ambil 3 spesimen. Hasil foto mikro spesimen baja St 42 antara lain sebagai berikut:

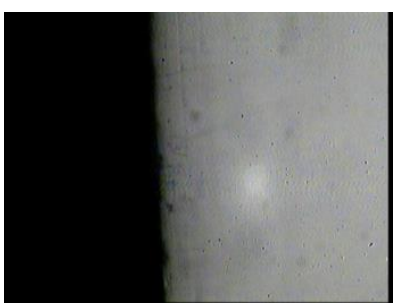

Gambar 4. Foto Mikro Baja St 42 Tanpa Perlakuan

Dari gambar 4 dapat dilihat bahwa baja St 42 tanpa perlakuan tidak mengalami difusi karbon pada permukaannya, sehingga tidak tampak batas antara daerah hypereutectoid dan hypoeutectoid. Permukaan baja St 42 terlihat belum terdapat tambahan unsur karbon. Hal ini dikarenakan baja St 42 ini belum dilakukan carburizing. Sehingga sifat mekanis dan fisisnya masih murni baja St 42.

hasil foto mikro spesimen baja St 42 yang telah mengalami proes carburizing dengan arang kayu jati pada temperatur $950{ }^{\circ} \mathrm{C}$ dan holding time selama 1 jam yang kemudian dilanjutkan quenching dengan media pendingin air dapat dilihat pada gambar $4.3-4.5$ di bawah ini:

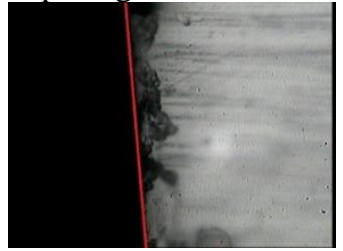

0,0

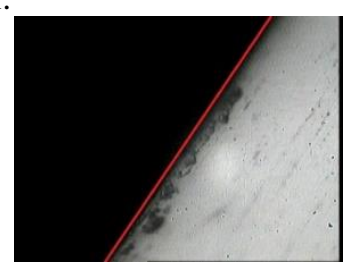

0,00

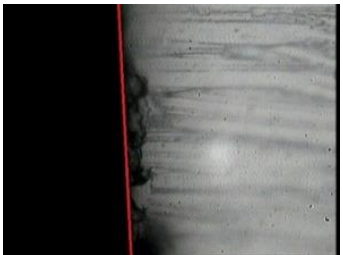

0,007

Gambar 5. Foto Mikro Baja St 42 Setelah Mengalami Proses Carburizing dengan Arang Kayu Jati 
Procedia of Engineering and Life Science Conference Vol. 1. No. 1 March 2021

Seminar Nasional \& Call Paper Fakultas Sains dan Teknologi (SENASAINS 1st)

Universitas Muhammadiyah Sidoarjo

Tabel 5. Hasil Kedalaman Karburasi Dengan Arang Kayu Jati

\begin{tabular}{ccc}
\hline \multirow{2}{*}{ No } & Spesimen & \multicolumn{2}{c}{ Kedalaman Difusi Karbon dengan perbesaran 400x dalam } \\
\hline 1 & $\mathrm{P}_{21}$ & 0,0075 \\
\hline 2 & $\mathrm{P}_{22}$ & 0,0080 \\
\hline 3 & $\mathrm{P}_{23}$ & 0,0100 \\
\hline & Rata-rata kedalaman difusi karbon dalam & 0,0085 \\
\hline
\end{tabular}

Foto mikro pada penelitian ini akan diambil 3 spesimen. Hasil foto mikro spesimen baja St 42 yang telah mengalami proes carburizing dengan arang tempurung kelapa pada temperatur $950{ }^{\circ} \mathrm{C}$ dan holding time selama 1 jam yang kemudian dilanjutkan quenching dengan media pendingin air dapat dilihat pada gambar berikut :

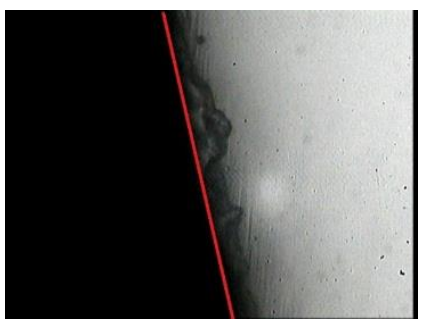

0,012

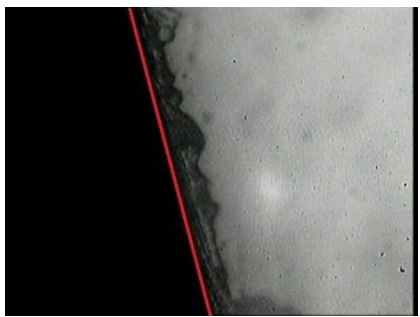

0,015

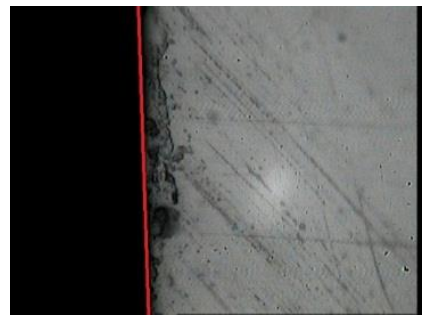

0,012

Gambar 6. Foto Mikro Baja St 42 Setelah Mengalami Proses Carburizing dengan Arang Tempurung Kelapa

Tabel 6. Hasil Kedalaman Karburasi Dengan Arang Kayu Jati

\begin{tabular}{ccc}
\hline No & Spesimen & \multicolumn{2}{c}{ Kedalaman Difusi Karbon dengan perbesaran 400x dalam } \\
\hline 1 & $\mathrm{P}_{21}$ & 0,0125 \\
\hline 2 & $\mathrm{P}_{22}$ & 0,0150 \\
\hline 3 & $\mathrm{P}_{23}$ & 0,0125 \\
\hline & Rata-rata kedalaman difusi karbon dalam & 0,0133 \\
\hline
\end{tabular}

Sedangkan foto mikro untuk sampel ke tiga adalah spesimen baja St 42 yang telah mengalami proes carburizing dengan arang kayu ukuran $15 \mathrm{~mm}-20 \mathrm{~mm}$ dengan temperatur $950{ }^{\circ} \mathrm{C}$ dan holding time selama 1 jam yang kemudian dilanjutkan quenching dengan media pendingin air dapat dilihat pada gambar berikut :

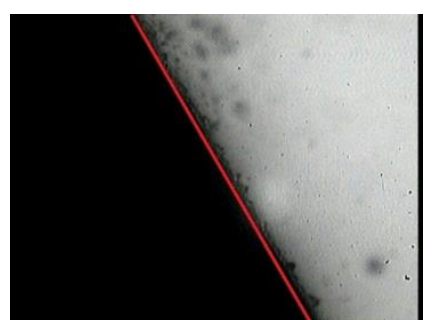

0,004

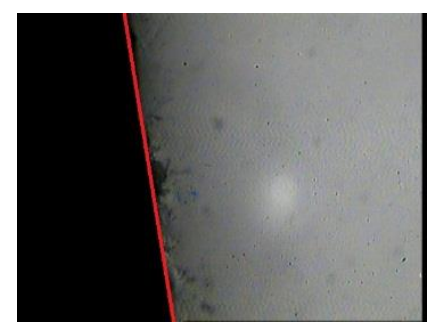

0,005

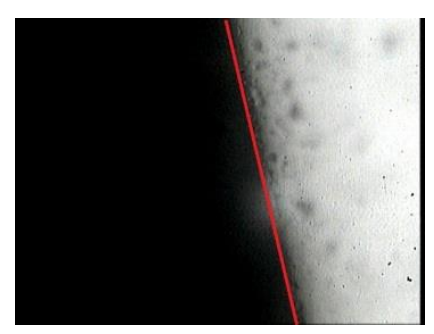

0,003

Gambar 7. Foto Mikro Baja St 42 Setelah Mengalami Proses Carburizing dengan Grafit 
Procedia of Engineering and Life Science Conference Vol. 1. No. 1 March 2021

Seminar Nasional \& Call Paper Fakultas Sains dan Teknologi (SENASAINS 1'st)

Universitas Muhammadiyah Sidoarjo

Tabel 7. Hasil Kedalaman Karburasi Dengan Grafit

\begin{tabular}{ccc}
\hline No & Spesimen & \multicolumn{2}{c}{ Kedalaman Difusi Karbon dengan perbesaran 400x dalam } \\
\hline 1 & $\mathrm{P}_{21}$ & 0,004 \\
\hline 2 & $\mathrm{P}_{22}$ & 0,005 \\
\hline 3 & $\mathrm{P}_{23}$ & 0,035 \\
\hline & Rata-rata kedalaman difusi karbon dalam & 0,00416 \\
\hline
\end{tabular}

Selain dalam bentuk tabel, hasil penelitian ini juga disajikan dalam bentuk grafik agar terlihat lebih jelas perbedaan nilai kedalaman karburasi pada baja St 42 setelah mengalami proses carburizing dengan variasi media donor yaitu arang kayu jati, arang tempurung kelapa, grafit pada temperatur $950{ }^{\circ} \mathrm{C}$. Grafik hasil pengujian kedalaman karburasi dapat dilihat pada gambar berikut :

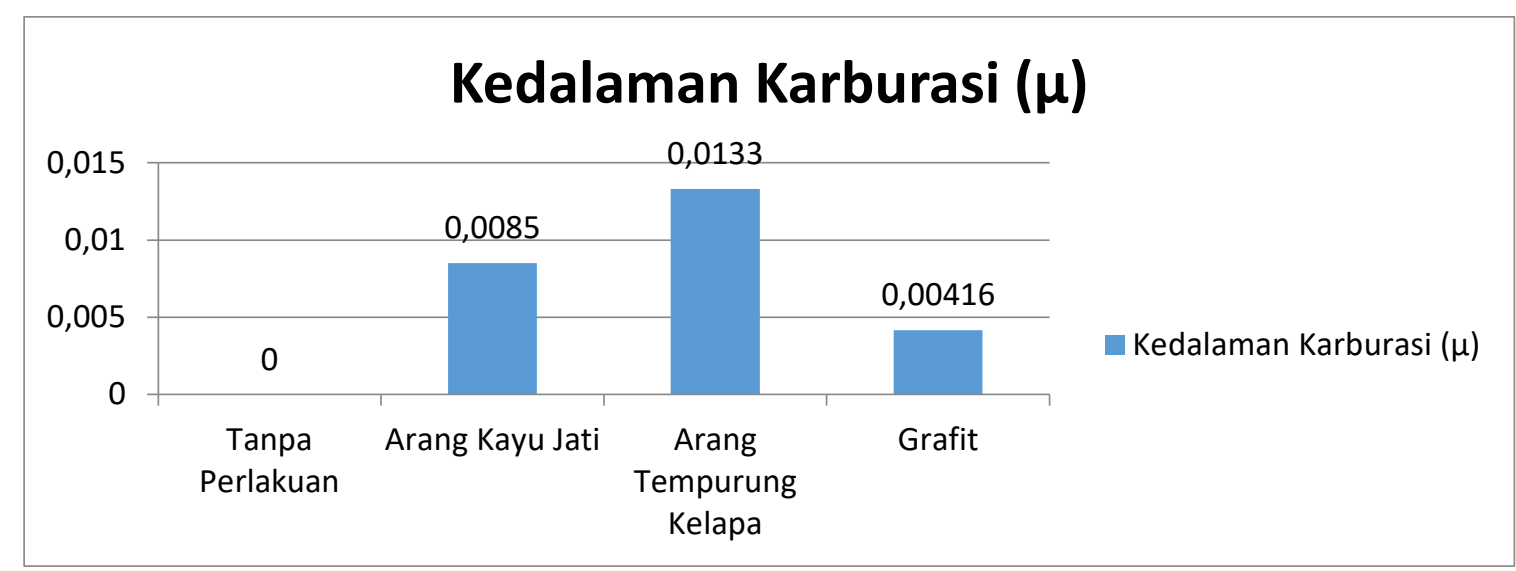

Gambar 8 Hasil Uji Kedalaman Karburasi Menggunakan Variasi Media Donor

Dari grafik diatas terlihat bahwa kedalaman karburasi terbesar adalah yang menggunakan media donor arang tempurung kelapa dengan $0,01330 \mu$, yang terbesar kedua adalah yang menggunakan arang kayu jati dengan 0,00850 $\mu$, kemudian yang terakhir adalah yang menggunakan grafit dengan 0,00416 $\mu$. Dengan demikian dapat ditarik kesimpulan bahwa hasil difusi terbaik pada proses karburasi adalah dengan menggunakan media arang tempurung kelapa.

\section{KESIMPULAN}

Dari penelitian yang telah dilakukan, didapatkan hasil bahwa proses karburasi untuk kekerasan dan kedalaman difusi karbon akan lebih efektif jika menggunakan arang tempurung kelapa. Hal ini disebabkan karena karakteristik arang tempurung kelapa yang lunak jika dibandingkan dengan media donor yang lain. Selain itu kandungan karbon dari arang tempurung kelapa lebih banyak dari pada media yang lain.

\section{REFERENSI}

[1] Istiqlaliyah, Hesti, 2016, Pengaruh Variasi Temperatur Anneling Terhadap Kekerasan Sambungan Baja ST 37 , Jurnal Teknik Mesin, Vol. 5 No. 4 Hal. 137-142, Universitas Mercubuana, Jakarta.

[2] Istiqlaliyah, Hesti, 2018, Analisa Kekerasan Logam Dengan Variasi suhu Karburasi Dan Media Pendingin Pada Proses Quenching, Flywheel, Vol. IV, No. 2, Hal. 79-81, Teknik Mesin Untirta, Banten.

[3] Vlack, Lawrence H. Van., 1992, Ilmu dan Teknologi Bahan. Erlangga, Jakarta.

[4] Lakhtin, Prof. Y., 1970, Engineering Physical Metallurgy, Mir Publishers, Moscow.

[5] Zakharov, B., 1962, Heat- Treatment Of Metals, Peace Publishers, Moscow. 